\title{
EVALUATION OF THE DIVERSITY \\ sciendo OF TRAINING QUALITY CONDUCTED AS PART OF GENERAL TRAINING AND ON-THE-JOB TRAINING - CASE STUDY
}

doi:10.2478/mape-2018-0086

Date of submission of the article to the Editor: 03/2018 Date of acceptance of the article by the Editor: 07/2018

Zygmunt Korban PhD, Eng.

Paweł Kołodziejczyk M.Sc., Eng.

Silesian University of Technology, Poland

Marcela Rabasová Mgr., PhD.

VSB -Technical University of Ostrava, Czech Republic
MAPE 2018, volume 1, issue 1, pp. 683-688

\begin{abstract}
The level of occupational health and safety is one of the determinants of the company's efficiency. The article assessed the quality of general initial training (general training) and initial training at the workplace (on-the-job training) carried out in selected business entities related to the hard coal mining industry. Problem included in the above trainings were interpreted as a criterion function within a multi-criteria analysis based on the Analytic Hierarchy Process (AHP) method. Application of the AHP method allowed to perform a diagnostic (comparative) assessment of objects (business entities), both objects and accepted assessment criteria were compared in pairs with each other (the evaluator's preferences (subjectivity of assessments) are treated in the Analytic Hierarchy Process as a natural phenomenon).
\end{abstract}

Keywords: safety, training, multi-criteria analysis.

\section{INTRODUCTION}

According to art. 66 of the Constitution of the Republic of Poland, everyone has the right to safe and healthy working conditions (Konstytucja, 1997). According to this article, the manner of implementing this right and the employer's obligations are specified in the Act. In addition, the employer's duty is to acquaint employees who are undertaking work with the scope of their duties and the way of work. Furthermore, the employer's obligation is to conduct regular employee training in the field of occupational health and safety: The Labor Code refers to the employer's obligation to conduct employee training before starting work, as well as the need for periodic training. Teaching and presenting are two very simple key words that fully reflect the sense and purpose of training in health and safety at work: an employee acquires theoretical knowledge about safe and healthy working conditions and has the opportunity to learn practical aspects of a safe way to perform work tasks. Carefully conducted trainings in the field of occupational health and safety allow the employee to become acquainted with procedures and technology as well as with threats at the workplace (both real and potential). This is extremely important from the point of view of making rational decisions, especially in life or health emergencies. This is particularly important when there is a frequent rotation of the staff and work in underground mines is undertaken by people without proper mining education. It is important to speak in a simple way, which means that while conducting trainings, topics related to occupational health and safety should be discussed in a comprehensible and understandable way for all employees. It seems that the identification of the needs of trainees should be started by defining the expectations of the persons supervising the work and during the training to focus on the tasks and professional activities performed by 
the employees. Making employees aware of occupational health and safety makes them aware of the dangers and risks that they may face during work and allows to shape the employees aware of the dangers and values of their and other employees lives - mainly due to natural hazard (Brodny and Tutak, 2016a; 2016b). This not only affects the individual behavior of trainees, but also helps to set a certain trend in the workplace, where compliance with health and safety rules is something obvious, and any deviation from this norm is noticed and punished.

\section{THE LEGAL REQUIREMENTS FOR WORK TRAINING}

Detailed provisions regarding health and safety training are contained in the Ordinance of the Minister of Economy and Labor of July 27, 2004. on training in health and safety at work (Rozporządzenie, 2004) and the Regulation of the Council of Ministers of September 2, 1997 on health and safety at work (Rozporządzenie, 1997). The first of these regulations defines:

- scope and detailed rules of conducting trainings in the field of occupational health and safety,

- requirements for the content and implementation of training programs and how to document them,

- cases in which employers or employees may be exempted from certain types of training.

The regulation also defines forms of training and the concept of an organizational unit conducting training activities in the field of occupational health and safety. According to the above regulation, the employer is required to:

- provide the employee with an appropriate training for the type of work,

- acquaint the employee with information and instructions regarding the position held, regulations and OHS rules as well as the scope of duties and responsibilities in the field of occupational safety and health,

- familiarizing the employee with environmental factors, hazards and exposures and with appropriate preventive measures and actions,

- provide the employee with the ability to perform work in a safe way for themselves and others, as well as for dealing with emergencies and first aid.

Regulation of the Council of Ministers of September 2, 1997 (with later changes) regarding the health and safety at work service defines the scope of activities of the OSH service concerning initial and periodic training:

- initial training (general introductory training, initial training at the workplace),

- periodic training is conducted to update and consolidate knowledge in the field of occupational health and safety, skills to work safely and familiarize employees with new technical and organizational solutions in this area. The completion of this training is compulsory for both engineering and technical staff, workers employed in workstations, as well as administrative and office employees.

\section{THE SUBJECT OF GENERAL AND ON-THE-JOB TRAINING AS ELEMENTS OF MULTI- CRITERIA ASSESSMENT}

According to the Regulation of the Minister of Economy and Labor of July 27, 2004 on training in the field of occupational health and safety, people taking general instructions during a minimum of 3 lessons (45-minute per lesson) should become familiar with the following topics:

1. General rules of health and safety at work.

2. The scope of duties and rights of the employer, employees and individual organizational units and social organizations in the field of occupational health and safety.

3. Responsibility for violation of health and safety rules.

4. Rules of moving around the workplace.

5. Accident hazards and health hazards present in the plant and basic preventive measures. 
6. Basic principles of occupational health and safety related to the operation of technical devices and internal transport.

7. The rules for the allocation of work clothing and working footwear as well as personal protective equipment in relation to the specific work station.

8. Workplace order and cleanliness - their impact on the health and safety of the employee.

9. Preventive medical care - the rules of exercising it in relation to the instructed position.

10.Basic principles of fire protection and firefighting.

11.Proceedings in the event of an accident, including organization and principles of first aid.

In the case of on-the-job training, the framework training program includes:

1. Preparing an employee to perform a specific job, in particular:

a) discussion of working conditions,

b) discussion of hazards occurring at specific activities at the workplace, results of occupational risk assessment related to the work performed and methods of protection against threats and also the rules of conduct in the event of an accident or breakdown,

c) preparation of work station equipment to perform a specific task.

2. A demonstration (by the instructor) how to perform work at the workplace in accordance with the provisions and principles of occupational health and safety, including the methods of safe performance of individual activities and with particular attention to difficult and dangerous activities.

3. Trial task by the employee under the supervision of an instructor.

4. Self-employee work under the supervision of an instructor.

5. Discussion and evaluation the course of work performed by an employee.

The above topics should be implemented within a minimum of eight 45 -minute class hours.

\section{RESEARCH RESULTS}

As part of the research process, the topics of general and on-the-job trainings were used as criteria for multi-criteria evaluation conducted using the Analytic Hierarchy Process (AHP) method (Anonymousa, 2010; Przybyła and Korban, 2010; Rabasová and Korban, 2016; Saaty, $1977 ; 1994 ; 2001 ; 2005)$ : in the case of general training there are 11 criteria (item 1 of the framework of general training corresponds to the function of criterion $K_{1}$, point 2 - criterion $K_{2}$, ...., point 11 - criterion $K_{11}$ ), in the case of on-the-job training - with 5 criteria (item 1 of the framework of on-the-job training program corresponds to the criterion $k_{1}$, point 2 - criterion $k_{2}$, ...., point 5 - criterion $k_{5}$ ). Research was carried out in three business entities and covered newly admitted employees and full-time students of the Faculty of Mining and Geology of the Silesian University of Technology, who were doing their one semester student practice. Thus, in the case of general training we deal with three objects subjected to evaluation (coal mine 1 corresponds to object $\mathrm{A}$, coal mine 2 - corresponds to object $\mathrm{B}$, and a company from mining industry - object $C$ ), we also deal with three facilities in the case of on-the-job training (three on-the-job training regarding a member of the transport crew were assessed): object a corresponds to on-the-job training in coal mine 1 , object $b$ corresponds to on-the-job training in coal mine 2, and object c - on-the-job training in company from mining industry.

The AHP method developed in 1970 by Thomas L. Saati, used in the article, is so called expert method, in which the assessments are determined on the basis of judgments of experts in a given field, and objects are evaluated and criteria are compared in pairs with each other.

In this method, the relative significance factor of criterion $K_{i}$ over $K_{j}$ is expressed by the parameter $a_{i j}$ being the quotient of the above-mentioned indicators $a_{i j}=r_{i} / r_{j}$ ( $r_{i}-$ absolute rank (importance) of the criterion) criterion $K_{i}, r_{j}-$ absolute rank (importance) of the criterion $K_{j}$ for $\left.i j=1,2,3 \ldots ..\right)$, which is assigned a verbal evaluation and a numerical value: object (variant) $x_{i}$ compared to the object (variant) $y_{i}$ in relation to the considered criterion may be preferred (Saaty, 1977; 1994): extremely (the numerical evaluation takes the value of 9), from very strongly to extremely (8), very strongly (7), from strongly to very strong (6), 
strongly (5), from moderately to strongly (4), moderately (3), from equivalent to moderate (2), equivalently (1).

The coefficients $a_{i j}$ are constituent elements of a square matrix, where $a_{j i}=1 / a_{i j}$ for $i=1,2 \ldots n$.

The results of tests are presented in tables from 1 to 5 .

Table 1

General training - comparison of objects in pairs within the next criteria

\begin{tabular}{|c|c|c|c|c|c|c|c|c|c|c|c|c|c|c|c|}
\hline & \multicolumn{3}{|c|}{$\begin{array}{c}\text { Criterion } 1 \\
\left(K_{1}\right)\end{array}$} & & \multicolumn{3}{|c|}{$\begin{array}{c}\text { Criterion } 2 \\
\left(K_{2}\right)\end{array}$} & & \multicolumn{3}{|c|}{$\begin{array}{c}\text { Criterion } 3 \\
\left(K_{3}\right)\end{array}$} & & \multicolumn{3}{|c|}{$\begin{array}{c}\text { Criterion } 4 \\
\left(K_{4}\right)\end{array}$} \\
\hline & $\mathbf{A}$ & B & C & & $\mathbf{A}$ & B & C & & $\mathbf{A}$ & B & C & & $\mathbf{A}$ & B & C \\
\hline $\mathrm{A}$ & & 3 & 2 & $\mathrm{~A}$ & & 2 & 3 & $\mathrm{~A}$ & & 2 & 2 & $\mathrm{~A}$ & & 2 & 2 \\
\hline$B$ & & & 2 & $B$ & & & 4 & $B$ & & & & $B$ & & & \\
\hline \multirow[t]{4}{*}{$\mathrm{C}$} & & & & $\mathrm{C}$ & & & & $\mathrm{C}$ & & 2 & & C & & 3 & \\
\hline & & & & & & & & & & & & & & & \\
\hline & \multicolumn{3}{|c|}{$\begin{array}{c}\text { Criterion } 5 \\
\left(K_{5}\right)\end{array}$} & & \multicolumn{3}{|c|}{$\begin{array}{c}\text { Criterion } 6 \\
\left(K_{6}\right)\end{array}$} & & \multicolumn{3}{|c|}{$\begin{array}{c}\text { Criterion } 7 \\
\left(K_{7}\right)\end{array}$} & & \multicolumn{3}{|c|}{$\begin{array}{c}\text { Criterion } 8 \\
\left(K_{8}\right)\end{array}$} \\
\hline & A & B & C & & A & B & C & & $\mathbf{A}$ & B & C & & A & B & C \\
\hline$A$ & & & 2 & A & & & & $A$ & & 2 & 5 & $A$ & & 3 & 3 \\
\hline B & 2 & & 3 & $B$ & & & & $B$ & & & 5 & $B$ & & & 2 \\
\hline \multirow[t]{4}{*}{ C } & & & & C & & & & C & & & & C & & & \\
\hline & & & & & & & & & & & & & & & \\
\hline & \multicolumn{3}{|c|}{$\begin{array}{c}\text { Criterion } 9 \\
\left(K_{g}\right)\end{array}$} & & \multicolumn{3}{|c|}{$\begin{array}{c}\text { Criterion } \\
10\left(K_{10}\right)\end{array}$} & & \multicolumn{3}{|c|}{$\begin{array}{c}\text { Criterion } \\
11\left(K_{11}\right)\end{array}$} & & & & \\
\hline & $\mathbf{A}$ & B & $\mathbf{C}$ & & $\mathbf{A}$ & B & C & & $\mathbf{A}$ & B & C & & & & \\
\hline$A$ & & 3 & 4 & $A$ & & 2 & 7 & $A$ & & 2 & 5 & & & & \\
\hline B & & & 3 & B & & & 8 & B & & & 5 & & & & \\
\hline$C$ & & & & C & & & & $\mathrm{C}$ & & & & & & & \\
\hline
\end{tabular}

The above comparison shows the "advantage" of the quality of general instructions implemented in coal mine 1 (object A). Only in the case of the criterion $K_{5}$ - Accident hazards and health hazards present in the plant and basic preventive measures the way of discussing the above-mentioned subject was rated higher in coal mine 2 (object B).

In the case of criterion $K_{6}$ - Basic principles of occupational health and safety related to the operation of technical devices and internal transport no differences were found in the quality of discussing the above-mentioned subject in all objects.

Table 2

General training - values of $\lambda_{\max }$ and compliance coefficients $c$ for individual criteria

\begin{tabular}{|c|c|c|}
\hline & $\lambda_{\max }$ & $c$ \\
\hline Criterion $1\left(K_{1}\right)$ & 3.137 & 0.092 \\
\hline Criterion $2\left(K_{2}\right)$ & 3.109 & 0.073 \\
\hline Criterion $3\left(K_{3}\right)$ & 3.054 & 0.036 \\
\hline Criterion $4\left(K_{4}\right)$ & 3.136 & 0.092 \\
\hline Criterion $5\left(K_{5}\right)$ & 3.009 & 0.006 \\
\hline Criterion $6\left(K_{6}\right)$ & 3.000 & 0.000 \\
\hline Criterion $7\left(K_{7}\right)$ & 3.054 & 0.036 \\
\hline Criterion $8\left(K_{8}\right)$ & 3.054 & 0.036 \\
\hline Criterion $9\left(K_{9}\right)$ & 3.074 & 0.050 \\
\hline Criterion $10\left(K_{10}\right)$ & 3.077 & 0.052 \\
\hline Criterion $11\left(K_{11}\right)$ & 3.054 & 0.037 \\
\hline
\end{tabular}

As a result of the AHP method, it can be concluded that in the case of general training, the relative weights for the final ranking of objects were respectively: object $A$ : 0.490 ; object $B$ : 0.318 ; object $C$ : 0.193 , which means that in the opinion of the evaluators, the quality of the 
general training implemented in object $A$ (coal mine 1) was rated the highest, and the lowest in object $C$ (company from mining industry).

Table 3

General training - comparison in pairs of criteria validity

\begin{tabular}{|l|l|l|l|l|l|l|l|l|l|l|l|}
\hline \multicolumn{1}{l|}{} & $K_{1}$ & $\boldsymbol{K}_{\mathbf{2}}$ & $\boldsymbol{K}_{\mathbf{3}}$ & $\boldsymbol{K}_{\mathbf{4}}$ & $\boldsymbol{K}_{\mathbf{5}}$ & $\boldsymbol{K}_{6}$ & $\boldsymbol{K}_{\mathbf{7}}$ & $\boldsymbol{K}_{\mathbf{8}}$ & $\boldsymbol{K}_{\mathbf{9}}$ & $\boldsymbol{K}_{10}$ & $\boldsymbol{K}_{11}$ \\
\hline$K_{2}$ & & & & & & & & & & & \\
\hline$K_{3}$ & & & & & & & & & & & \\
\hline$K_{4}$ & & & & & & & & & & & \\
\hline$K_{5}$ & 2 & 2 & & 2 & & & 3 & 2 & 2 & 2 & \\
\hline$K_{6}$ & & & & & & & & & & & \\
\hline$K_{7}$ & & & & & & & & & & & \\
\hline$K_{8}$ & & & & & & & & & & & \\
\hline$K_{9}$ & & & & & & & & & & & \\
\hline$K_{10}$ & & & & & & & & & & & \\
\hline$K_{11}$ & & & & & & & & & & & \\
\hline
\end{tabular}

On similar terms, the quality of on-the-job training was assessed - in this case, three trainings were implemented in the abovementioned business entities (two coal mines and a company from mining industry).

Table 4

On-the-job training - comparison of objects in pairs within the next criteria

\begin{tabular}{|c|c|c|c|c|c|c|c|c|c|c|c|c|c|c|c|c|c|c|c|}
\hline & \multicolumn{3}{|c|}{$\begin{array}{c}\text { Criterion } 1 \\
\left(k_{1}\right)\end{array}$} & & \multicolumn{3}{|c|}{$\begin{array}{c}\text { Criterion } 2 \\
\left(k_{2}\right)\end{array}$} & & \multicolumn{3}{|c|}{$\begin{array}{c}\text { Criterion } 3 \\
\left(k_{3}\right)\end{array}$} & & \multicolumn{3}{|c|}{$\begin{array}{c}\text { Criterion } 4 \\
\left(k_{4}\right)\end{array}$} & & \multicolumn{3}{|c|}{$\begin{array}{c}\text { Criterion } 5 \\
\left(k_{5}\right)\end{array}$} \\
\hline & $a$ & $b$ & $c$ & & $a$ & $b$ & $c$ & & $a$ & $b$ & $c$ & & $a$ & $b$ & $c$ & & $a$ & $b$ & $c$ \\
\hline$a$ & & 2 & 2 & $a$ & & 2 & 2 & $a$ & & 3 & 5 & $a$ & & 4 & 2 & $a$ & & & 3 \\
\hline$b$ & & & 2 & $b$ & & & & $b$ & & & 4 & $b$ & & & & $b$ & 2 & & 2 \\
\hline$c$ & & & & $C$ & & 4 & & $c$ & & & & $c$ & & 5 & & $C$ & & & \\
\hline
\end{tabular}

Compared to coal mine 1 and coal mine 2 in the company from mining industry only in case of the criteria $k_{2}-A$ demonstration (by the instructor) how to perform work at the workplace (...) and $k_{4}$ - Self-employee work under the supervision of an instructor the quality of the subject has been assessed better.

Table 5

General training - values of $\lambda_{\max }$ and compliance coefficients $c$ for individual criteria

\begin{tabular}{|l|c|c|}
\cline { 2 - 3 } \multicolumn{1}{c|}{} & $\lambda_{\max }$ & $c$ \\
\hline Criterion 1 $\left(k_{1}\right)$ & 3.054 & 0.060 \\
\hline Criterion 2 $\left(k_{2}\right)$ & 3.220 & 0.247 \\
\hline Criterion 3 $\left(k_{3}\right)$ & 3.087 & 0.097 \\
\hline Criterion 4 $\left(k_{4}\right)$ & 3.095 & 0.107 \\
\hline Criterion 5 $\left(k_{5}\right)$ & 3.136 & 0.153 \\
\hline
\end{tabular}

In the case of comparison with the validity pairs of the criteria, the same level of validity was adopted (equivalent assessment corresponding to the numerical evaluation of 1 ).

The final result allows to conclude that in the case of on-the-job training, the relative weights for the final ranking of the facilities were respectively: object $a$ : 0.492 ; object $b$ : 0.267 ; object c: 0.242 , which means that in the opinion of the assessors, the quality of on-the-job training realized in the object a (instructing a member of the transport crew in a coal mine 1) was rated the highest, and the lowest in the object $c$ (company from mining industry). 


\section{CONCLUSIONS}

The hierarchical analysis method (Analytic Hierarchy Process) belongs to one of the more frequently used one for solving decision problems. This method, which is an example of multicriteria discrete methods, is particularly useful in the process of variation of variants (objects), when the assessment criteria (all or part of them) are qualitative. Although this method has the risk of obtaining a result burdened with the subjective assessment of the assessor, however, proper formal preparation and professional experience of the decision maker allows to minimize this inconvenience.

In this article, the AHP method was used to diversify the quality of initial training (general and on-the-job training) conducted in selected mines and mining companies. Obtained results (rankings) allow to identify strengths and weaknesses of conducted trainings, which may be helpful in the case of taking actions aimed at increasing the trainings quality level. According to the authors, this is all more important because underground work is undertaken by people just starting their careers, who often do not have any experience or proper professional training.

\section{REFERENCES}

Konstytucja Rzeczpospolitej Polskiej z dnia 2 kwietnia 1997 r. (Dz.U. 1997 nr 78 poz. 483 z zm.).

Brodny, J. and Tutak, M. (2016a). Determination of the zone endangered by methane explosion in goaf with caving of operating longwalls. 16th International Multidisciplinary Scientific GeoConference. SGEM, Albena, Bulgaria. Conference proceedings. Book 1, Science and technologies in geology. Vol. 2, STEF92 Technology, pp. 299-306.

Brodny, J. and Tutak, M. (2016b). The impact of the flow volume flow ventilation to the location of the special hazard spontaneous fire zone in goaf with caving of operating longwalls. 16th International Multidisciplinary Scientific GeoConference. SGEM, Albena, Bulgaria. Conference proceedings. Book 1, Science and technologies in geology. Vol. 2, STEF92 Technology, pp. 897-904.

Rozporządzenie Ministra Gospodarki i Pracy z dnia 27 lipca 2004 r. w sprawie szkolenia w dziedzinie bezpieczeństwa i higieny pracy (Dz. U. 2004 nr 180 poz. 1860 z zm.).

Rozporządzenie Rady Ministrów z dnia 2 września 1997 r. w sprawie służby bezpieczeństwa i higieny pracy (Dz. U. 1997 nr 109 poz. 704 z zm.).

Anonymousa (2010). Analytical hierarchy process (AHP). [online] Available at: http://rfptemplates.technologyevaluation.com/Analytical-Hierarchy-Process-(AHP).html [Accessed 15 Apr. 2017].

Przybyła, H. and Korban, Z. (2010). Wielowariantowa ocena doboru rozwiązań technicznych przy wykorzystaniu metody AHP. Sbornik z 19 seminmare: W: Moderni matematické metody v inženýrstvi. Vysoka Skola Banska - Technicka Univerzita Ostrava, Jednota Ceskych Matematiku a Fyziku. Pobocka Ostrava, Katedra Matematiky a Deskriptivni Geometrie VSB-TU Ostrava. Ostrava : VSB - Technicka Univerzita Ostrava, pp. 108-112.

Rabasová, M. and Korban, Z. (2016). Wykorzystanie metody Analytic Hierarchy Process do oceny jakości zarządzania bezpieczeństwem i higieną pracy w kopalniach węgla kamiennego. Wiadomości Górnicze, 67(6), pp. 386-389.

Saaty T. L. (1977). A scaling method for priorities in hierarchical structures. Journal of Mathematical Psychology, 15, pp. 234-281.

Saaty, T. L. (1994). Fundamentals of Decision Making and Priority Theory with the Analytic Hierarchy Process. Pittsburgh: PA: RWS Publications.

Saaty, T.L. (2001). Fundamentals of the analytic hierarchy process. In: Schmoldt D.L, J. Kangas, G. A. Mendoza and M. Pesonen, ed., The analytic hierarchy process in natural resource and environmental decision making. Netherlands: Kluwer Academic Publishers, pp. 15-35.

Saaty, T. L. (2005). Analytic Hierarchy Process, Encyclopedia of Biostatistics. John Wiley \& Sons, Ltd. 